\title{
THE UNIVERSITY OF WARWICK
}

University of Warwick institutional repository: http://go.warwick.ac.uk/wrap

This paper is made available online in accordance with publisher policies. Please scroll down to view the document itself. Please refer to the repository record for this item and our policy information available from the repository home page for further information.

To see the final version of this paper please visit the publisher's website. Access to the published version may require a subscription.

Author(s): Jonathan S. Davies

Article Title: The hollowing-out of local democracy and the 'fatal conceit' of governing without government

Year of publication: 2002

Link to published article:

http://dx.doi.org/10.1111/1467-856X.00044

Publisher statement: The definitive version is available at wileyonlinelibrary.com 


\title{
The Hollowing Out of Local Democracy and the 'Fatal Conceit' of Governing without Government
}

\author{
Jonathan. S. Davies
}

\section{Books Reviewed}

Stewart J (2000) The Nature of British Local Government. Basingstoke: Macmillan

ISBN 0-333-66569-4 viii + 310pp

Stoker G (ed) (1999) The New Management of British Local Governance. Basingstoke: Macmillan ISBN 0-333-72815-7 xxvi + 280pp

Stoker G (ed) (2000) The New Politics of British Local Governance. Basingstoke: Macmillan ISBN 0-333-72818-1 xvii + 294pp

\section{Introduction}

On $4^{\text {th }}$ May 2000, Ken Livingstone was elected Mayor of London on a turn-out of only 33.6\%, a day when around $30 \%$ of voters turned out in local council elections. New Labour has broadcast its intention to revive participation in local democracy and these voting figures undermine the credibility of its policies. Now is therefore a good time to ask whether recent research into local politics sheds any light on problems of local governance and democracy. Three recent texts published by Macmillan in the Government Beyond the Centre series provide useful insights into local political processes, covering The New Management of British Local Governance (Stoker, 1999), The New Politics of British Local Governance (Stoker, 2000), and The Nature of British Local Government (Stewart, 2000).

The two companion volumes edited by Gerry Stoker represent the findings of research carried out under the umbrella of the ESRC Local Governance Programme (LGP) over a period of five years between 1992 and 1997. The findings are grouped loosely around the themes of 'management' and 'politics'. Local governance can be defined as a process in which governing outcomes depend on the interactions of a complex set of institutions and actors drawn from, but also beyond, local government (see Stoker, 1998: 19). Being concerned with local governance, rather than with local government, the contributors focus on the interactions between institutions and actors more than on processes occurring within the local authority. Unsurprisingly, the broad themes of management and politics overlap and many of the twenty eight contributions would fit equally well under the headings of management or politics. 
John Stewart's monograph, The Nature of British Local Government (Stewart, 2000), takes a different approach, focusing instead on changing processes within local government itself. While the book is not a challenge to the concept of local governance, it serves as a reminder that local authorities still sit at the apex of local political processes. Stewart's volume also contrasts with the LGP as a general introduction to the politics and management of local government over a period of up to 200 years. In this sense, it probably serves better as an introductory text than as an example of cutting-edge research. Its virtue is the depth of experience which the author has gained over many years, conveyed in anecdotes and examples covering every aspect of local politics since the nineteenth century.

Using this method, Stewart paints many revealing portraits in pursuit of two main claims. First, he argues, local government is characterised as much by continuity as by change and that many aspects of the new world of local government are inherited from the recent and the not so recent past. Again, this argument is not an attack on the concept of local governance, but a recognition that local government at the beginning of the twenty-first century has inherited many of its current attitudes, customs and practices from the twentieth and even the nineteenth centuries. For example, a key theme which Stewart highlights is the continuation of a paternalistic and professional ethos within local government which serves to undermine public participation in political decision making.

Stewart's second argument is that there are tendencies toward uniformity and diversity in the practice of local government. The fact that local government is working to a centrally inspired policy agenda in arenas such as 'best value' and 'community governance' does not mean, says Stewart, that it cannot respond to this agenda in diverse and creative ways which sometimes frustrate the intentions of the legislator. Compulsory Competitive Tendering (CCT), for example, has not resulted in the privatisation of all local government services. Many local authorities retain a strong commitment to the provision of in house services. As Doogan argues of CCT in his contribution to The New Management, the local authority has significant power in determining contract specifications. If it wants to retain a service inhouse, the chances are that it will be able to (Doogan, 1999). 
The issues of continuity and change and uniformity and diversity underpin much of the material arising from the LGP. None of the volumes offer an overall evaluation of the balance between these polarities, but they imply that on balance, the capacity for local autonomy and local political expression has not been enhanced by 'governance'. This review explores this claim further by examining the relationship between local governance and participation discussed in the texts.

\section{Local Governance as Networking}

For Rhodes, the concept of 'governance' developed in the LGP refers to self-organising, interorganisational networks characterised by interdependence between organisations, continuing interactions between network members, game like interactions rooted in trust and subject to rules negotiated by network participants, and a significant degree of autonomy from the state (Rhodes, 1999:

xvii). It is the outcome of processes which Rhodes elsewhere characterises as 'the hollowing out of the state' (See Rhodes, 1996: 661). Although markets and hierarchies vie with networks in this new world of local governance, networking is described by Rhodes as 'pervasive' (Rhodes, 2000: xiv-xv). Horizontal networking between interdependent and autonomous local organisations is therefore central to the governance concept as Rhodes sees it and evidence of local networking is evidence of local governance.

The impact of networking on local democracy is one of the more controversial elements in the governance discussion. Beynon and Edwards (1999) highlight the argument between those who believe that partnerships and networks undermine accountability by taking away from the elected councillor role and those who argue that networking empowers local citizens by providing opportunities for direct participation in decision making. Whatever the reasons for the decline of local democracy, the most important question posed by the authors is whether new forms of participation are regenerating the local polity. Several of the contributors to the LGP pose the question of how far local governance structures have become embedded and what effect they have had on local participation. They question how much autonomy these structures have from central government, the nature of citizen participation within them and the relationship between these two factors. The following paragraphs highlight the main 
themes which emerged from these contributions, and they evaluate the relevance to local politics of Rhodes' conceptualization of governance by network.

\section{Hierarchies Versus Networks}

Pollitt et al (1999) in examining the experience of opting out in health, education and housing, make a distinction between political and administrative decentralisation. The former denotes the delegation of political authority, the latter the delegation of administrative powers. In all three arenas, they identified little evidence of user empowerment, but rather a tendency toward political centralisation. Thus, while local authorities have handed over administrative powers to grant maintained schools and to housing associations, thereby 'letting managers manage', this tendency has been offset by increases in government control over policy and resources through agencies like the Housing Corporation (1999: 43).

This conclusion is reflected in the findings of other contributors. Barnes et al, in their analysis of the governance of community care, argue that 'users' are permitted only limited involvement in care planning. They suggest that local officials engage in 'strategic micro-politics', that is they gain legitimacy from a user group when its views are acceptable, yet disregard it when they are not (Barnes et al, 1999: 120). This case supports Stewart's view that the professional, paternalistic attitude remains a powerful element in the inheritance bequeathed by local government to the era of local governance (Stewart, 2000: 263).

A hierarchical pattern also emerges in many of the regeneration oriented partnership initiatives promoted by the current government and its predecessor. Beynon and Edwards (1999) show how community governance of crime control partnerships is undermined by the centrally determined institutional framework and by over-bureaucratised organisational forms in which the partnerships operate. Many regeneration partnerships exist only by virtue of their ability to attract governmental funds. Consequently, their ability to develop strategies which correspond with local interests are severely constrained. Morgan et al agree, suggesting that local economic development networks in 
Wales are characterised by short-termism and by reactive responses to external pressures including the grant regime.

...the presence of regional institutions in Wales presents us with an uncomfortable paradox, namely that the Welsh Office, by virtue of its power and resources, tends to foster vertical networks which have the effect of disempowering local actors from building effective horizontal networks (Morgan et al, 1999: 194).

For Beynon and Edwards and for Morgan et al, the reliance of partnerships on non-local sources of funding severely constrains their capacity to develop strategies around the interests of local populations. Where local people have an input into determining strategy, it is only on condition that their priorities coincide with those of the funding body. For example, when local people in Leicester proposed a motor project to work with youths who had been involved in car crime on a local estate, it was vetoed by the funding body because it was deemed too expensive (Beynon and Edwards, 1999: 162).

The picture is similar in the world of housing policy. Murdoch et al (2000), argue that planning for housing is 'exclusionary'. Local opinions on housing plans are marginalised with local decisions being based on national forecasts which are handed down for implementation in regions and localities. Based on government forecasts, local housing plans are decided by local officials who invoke their professional qualifications to block political objections. Murdoch et al perceive that consultation is symbolic and that local people must accept the housing plan, whether they like it or not. In this arena too, the paternalistic inheritance of local government remains strong within a hierarchical axis of decision making between centre and locality. Planning for housing is government by hierarchy, not governance by network.

Clapham et al (2000) evaluate the local governance of housing in their study of community based housing organisations (CBHOs) responsible for managing housing services in Glasgow. These bodies have, since the mid-1980s, provided an opportunity for local activists to participate in housing management and have delivered better accountability mechanisms for local tenants. But they have little political power in an environment where Scottish Homes, the government housing agency in Scotland, effectively controls development policy and funding. Clapham et al agree with the Nolan Committee which concludes that funding bodies are 'over-directive' toward local housing associations. They 
conclude that CBHOs are primarily vehicles for delivering the government's agenda for restructuring social housing, rather than a springboard for local democracy and local autonomy.

\section{Markets Versus Networks}

Ranson et al (1999), in their study of the new management and governance of education, show how marketisation can also undermine networking and democratic accountability, re-enforcing privileged interests against those of the wider public. They argue that if a school were to agree with the local community that it should recruit more ethnic minority students, it would be difficult to carry out this decision, given the ability of individuals to move their children to other schools. Thus, market 'choice' can have the effect of undermining confidence in community agreements because it makes them unsustainable. It gives 'exit' options to individuals, but undermines the wider community network.

The market as a result places collective welfare beyond the reach of public deliberation, choice and action: in other words, democracy' (Ranson et al, 1999: 105).

Unsurprisingly, it is socially disadvantaged families which lose out to the privileged families who exercise this 'exit' option and Ranson et al (1999: 106) argue that the market in education

entrenches the powerful beyond control. The doctrine of marketisation colludes in promoting the agency and choice of the public while actually extinguishing it.

Marketisation can undermine confidence in local agreements and networks by re-enforcing social hierarchies and social exclusion.

These accounts show that democratic networking mechanisms have often been inhibited or undermined by hierarchical control and by marketisation. Local participation and local diversity are encouraged, as long as the game is played within a set of rules established by the government and its agencies. But whatever capacity local communities might possess for participation through new structures of governance is undermined by centralising tendencies. While the conclusions drawn by the authors are often qualified, the over-riding impression which emerges from the LGP is that market, hierarchy and network stand in dynamic contradiction to one another, a contradictory relationship in which local networking is not taking root. 


\section{The Potential for Governance as Networking}

However, the LGP also shows that hierarchy is not necessarily pervasive in local governance and that where local autonomy exists, networking processes are easier to establish. Riley (1999: 173) follows the distinction made by Pollit et al (1999: 42) between policy and administration networks, arguing that the latter are easier to establish because participants perceived that they were solving common problems based on trust, common language and shared values (Riley, 1999: 174). Parity of status between members was important in helping to establish and maintain networks in post-16 education. For Morgan et al, Bristol is emerging as an exemplar of locally generated public-private partnerships. They argue that the absence of a central authority in the West of England meant that networking tended to be horizontal in character ...

And in the Avon area, these networks were largely self-generated, thereby encouraging selfreliance rather than dependence on a powerful regional institution (Morgan et al, 1999: 195).

John and Cole draw a similar lesson from their study of networking in Leeds and Rennes: that where there is no driving force from central government, where the Government steers instead of rowing, 'interorganisational relationships have their own life and ... they continually mutate' (John and Cole, 2000: 87).

\section{The Development of Local Governance - An Overview}

As far as participation and networking in local governance are concerned, it is possible to draw three main conclusions from the three studies. First, governance by network is not 'pervasive', as Rhodes claims in his second foreword to the LGP (2000: xiv). On the contrary, while there are exceptions to this picture, the new politics and the new management of local governance are characterised by vertical central-local and local-local networks which appear to be growing stronger, not weaker. Second, to the limited extent that the authors find networking is occurring, it is easier to build and sustain where the influences of central government and its agencies are weakest. Third, while local people have become involved in new forms of participation, these forms have not generally given rise to local political autonomy or to citizen empowerment. Participatory strategies have not resulted in bottom-up networks in part because they are constrained by the hierarchical tendencies discussed above. 
The following paragraphs consider further why hierarchy appears to be the prevalent mode of local governance. The conclusions reached are inferred and are partly speculative, but the evidence presented by the authors suggests that they are plausible.

\section{Hierarchy as Government Policy}

The results of the local elections on $4^{\text {th }}$ May show that insofar as new modes of political participation have been introduced through the governance processes discussed above, they have failed to reinvigorate local democracy. Should we treat this fact as a case of what Jessop (2000) describes as 'governance failure'? The answer to this question very much depends on standpoint. For advocates of community governance like Stewart, Jessop, Young and Murdoch et al, the picture painted in the LGP findings would be viewed as governance failure or, using Rhodes' definition, as 'non-governance'. After all, many of these schemes have been operating for at least 10 years, a period perceived in policy implementation analysis as long enough for new initiatives to bed-down and take full effect (see Marsh and Rhodes, 1992). Yet the fact that democratic renewal through networking has not occurred is at least in part attributable to centralising policies which have been consciously carried out by New Labour. Stewart highlights a contradiction in 'New Labour' between the government's commitment to decentralisation and its tendency to centralise which is evident in the White Paper Modern Local Government (DETR, 1998) and in service specific initiatives, including those in health and education.

It is relevant to note the attitude which the Government has taken to decentralisation at the regional level. The attempts to 'nobble' Ken Livingstone and Rhodri Morgan speak for themselves. The timid moves toward English regionalism also indicate reluctance on the part of the Government to relinquish control. Regional Development Agencies may yet turn out to be little more than agencies of central government. At best, the evidence suggests that the government is equivocal about decentralisation to the regions. The case of local governance suggests that the Blair Government is highly sceptical about allowing local political autonomy. Instead, as Jessop suggests, it seems to be using governance mechanisms to extend the reach of the state into civil society in its own interests (Jessop, 2000: 22). Stewart's evidence suggests that this approach may be deliberate. 
Quoting Jones and Travers (1996), Stewart highlights a common view among ministers and civil servants that the 'quality of local government members is not as good as it used to be, and not good enough by any standards'. The 'calibre' of councillors is presumed to be low and to be becoming lower, a perspective which Stewart perceives as 'elite contempt' (Stewart, 2000: 95/6). Tony Blair has charged local government with 'changing again so that you can play your part in helping to modernise Britain'. Crucially, this modernisation is necessary so that local government can, 'in partnership with others, deliver the policies for which this government was elected' (Blair quoted in Stewart, 2000: 121 ((my emphasis)). Blair promises an enhanced role to those who 'accept the challenge' and threatens those who are 'unwilling or unable to work to the modern agenda' with marginalisation. Correspondingly, the measures proposed in Modern Local Government are a mixture of incentives and sanctions (Stewart, 2000: 123).

This approach reflects the 'elite contempt' which Stewart describes and it provides a clear philosophical basis for New Labour to further entrench the hierarchical political relationships identified by the authors. Local authority leaders and officers cannot be trusted. 'Trust' is a key ingredient in Rhodes' conception of networking and despite the new rhetoric of partnership from government minsters (see Stoker, 1999: 17), 'trust' is still missing from the central-local axis. Local authorities are not accorded the right to make local political choices. They are seen as junior 'partners' of the centre, not as instruments of local political autonomy. It follows that until the government sees sufficient evidence of conformity, there is no reason to expect it to relax its control over local politics. While it may be true that there is a contradiction embodied in different government initiatives, the development of autonomous local networks will not be encouraged at the expense of the 'modernisation' agenda. If modernisation somehow succeeds in delivering Blair's vision of efficient and effective local government, but fails to re-invigorate local democracy, this outcome may be a price which 'New Labour' is willing to pay. Political centralisation is intentional and, from the point of view of 'New Labour', it may result in successful governance. In this political environment, it is not surprising that there is no firm trend in the direction of governance by network and there is no reason at present to believe that networking will become 'pervasive'. 
Given the degree of hierarchical control over many participatory processes, it is questionable whether New Labour has created sufficient incentives to convince local people that participation in community governance is worthwhile. Is it not reasonable to suppose that participation in politics at any level requires some optimism that 'governance' will bring about the popular will? Is it not reasonable also to suppose that participation depends on the belief that it will serve to bring about a better future? The authors show how vertical networks undermine participation from the top-down, but they also point toward factors which undermine participatory strategies from the bottom-up.

\section{Resources and Participation}

Two contributors show that the impact of participation is structurally constrained and circumscribed by inadequate resources. For Young, consultation and participatory schemes around Local Agenda 21 can have an impact on local recycling facilities, allotments and playgrounds. However, these plans will not deliver a multi-purpose community centre or better public transport. Options are constrained within narrow budgetary limits and Young remains uncertain about whether participatory mechanisms allow for significant policy choices (Young, 2000). Abrar's research on local domestic violence policy demonstrates that success in changing local policy is easiest where resources are plentiful. The degree of difficulty experienced by women in getting housing policy to prioritise domestic violence cases was directly related to resource scarcity, and financial cutbacks have led to cuts in provision for women facing domestic violence (Abrar, 2000: 265-7). The question is, then, whether it is possible to create a dynamic for political participation in localities which lack the resources to fulfil local aspirations. Is consultation on possible measures within top-down budgets a sufficient stimulus to participation, however 'user-friendly' the mechanism? That money matters is an obvious point to make, but the financial situation facing 'local governance' does not auger well for a renaissance in local democracy.

\section{Social Optimism and Political Participation in Community Governance}

The question of the relationship between resource constraints and participation brings me on to my final speculation concerning the role of optimism in governance processes. One of the best features of Stewart's monograph is the way it places local government in a historical context going back to the nineteenth century, a time when the possibilities for municipal government were being explored. The 
'municipal gospel' in Birmingham was proclaimed by the Reverend George Dawson, a social visionary, leading to

... the discovery that perhaps a strong and able Town Council might do almost as much to improve the conditions of life in the town as Parliament itself. I have called it a 'discovery', for it had all the freshness and charm - it created all the enthusiasm - of a good discovery. One of its first effects was to invest the Council with a new attractiveness and dignity ... The November ward meetings assumed a new character. The speakers, instead of discussing small questions of administration and of economy, dwelt with growing enthusiasm on what a great and prosperous town like Birmingham might do for its people. They spoke of sweeping away streets in which it was not possible to live a healthy and decent life; of making the town cleaner, sweeter and brighter; of providing gardens and parks and music; or erecting baths and free libraries, an art gallery and a museum ... Sometimes an adventurous orator would excite his audience by dwelling on the glories of Florence and of the other cities of Italy in the middle ages, and suggest that Birmingham, too, might become the home of a noble literature and art (Dawson, quoted in Gill, 1952: 382, cited in Stewart, 2000: 28).

The message from this inspiring statement which seems relevant today is that social optimism has an invigorating effect. In the nineteenth century, municipalism, correctly or not, was perceived as an instrument to end deprivation and to achieve an ambitious vision for the future. The point is not that Birmingham never became Florence, but that social optimism drove activity and participation.

It is difficult to detect, even within the most committed 'New Labour' authorities, a vision of community governance to replace this municipal doctrine. This is not an era in which we are building free libraries, but an era of library charges and library closures. It is an era in which gardens and parks are being sacrificed to developers, swimming baths are closing and arts budgets are being cut to the bone. The evils of city life described by Dawson have returned with a vengeance, if indeed they ever went away. Regeneration for many cities and towns means flexible labour and low wages, empty brown-field sites and exclusive town centre developments. It means islands of prosperity within oceans of deprivation. For thousands of workers in the motor industry around Birmingham, the future is unemployment and social exclusion. Stewart quotes Wilson who argued that:

If men are clear that what they hope to get out of local government is not only sweeter drains, roomier buses, greener parks, but an exercise of their own adult civic responsibility and political education then the foundation of local government is sound, and soundly understood (Wilson, quoted in Stewart, 2000: 42).

It could be asked in addition: unless 'men' can realistically hope to get sweeter drains, roomier buses and greener parks from the processes of local governance, thereby making the foundation of local 
governance sound, is there any good reason why they would exercise their adult civic responsibility and political education? The question facing advocates of community governance is how to create a sustainable dynamic for participation in a difficult socio-economic environment where levels of social optimism are often very low. Time will tell, but the prognosis offered here is negative.

\section{Conclusion}

The strength of all three texts is that they provide an excellent basis upon which to analyse the current state of 'local governance' and to speculate on possible trends. The weakness they share is that they do not undertake this task themselves. In the case of the Local Governance Programme, a concluding chapter could have offered a retrospective comment on the validity of Rhodes' initial premise. Stewart, on the other hand, might have given a more explicit opinion on the current balance he perceives between continuity and change and uniformity and diversity. Instead, he says only that "whether there is a sufficient capacity for diversity within the necessity of uniformity' remains to be seen (Stewart, 2000: 290). However, the evidence points toward a number of conclusions.

The main conclusion is that the world of governance as networks, which Rhodes perceives, does not exist in the realm of local politics. Networking is occurring but it does not resemble the highly specific concept of autonomous governance which, he says, formed the centrepiece of the Local Governance Programme (Rhodes, 1999: xvii). There are three reasons which can be inferred from the authors to explain why Rhodes' 'governance' has not become pervasive. First, the mechanisms of local governance are often, if not always, subject to strong political controls by central government, which undermines autonomous networking. Second, there remains a strong culture of paternalism and professionalism within local government itself, which undermine the confidence of 'users' in governance mechanisms. Third, current socio-economic conditions do not suggest that new participatory mechanisms will unleash a pent-up enthusiasm for community participation in local governance. On the contrary, they probably act as a disincentive. For these reasons, as Morgan et al state, the notion of 'governing without government' is a 'fatal conceit' (Morgan et al, 1999: 196). There is scant evidence of a renaissance in local participation, and it may be more accurate to characterise the processes discussed here as the 'hollowing-out' of local democracy. 
It was suggested above that the process of local governance described by the authors more closely resembles vertical networking, with government rowing, than it does horizontal networking, with government steering. A conclusion of this nature offers pointers for future research strategies. A world of autonomous, local networks might lead political scientists to focus on the internal process of collaboration between local actors in developing explanations for local political outcomes. A world of vertical policy networks, on the other hand, means that extra-local factors, in this context central government, remain critical to a rounded understanding of local politics. Another important extra-local factor explaining local political outcomes may be 'globalisation' in its many guises. Both vertical and horizontal networks can be analysed within a broader political economy approach, as the LGP demonstrates (Harding, 2000; Painter and Goodwin, 2000).

Several of the authors involved in these studies share, to a greater or a lesser extent, the normative agenda for stakeholding, for citizen participation and for community governance set out by Tony Blair. The findings these authors report are unlikely, however, to leave them with a sense of optimism about the prospects for democratic renewal through the processes of governance they discuss. The potential for achieving democratic governance in the context of vertical networks is therefore an obvious research agenda for like-minded scholars to pursue. Finally, Stewart's picture of continuity and change suggests that the concept of local governance is likely to remain contested. Moreover, in a policy environment where localities are bombarded with new initiatives from government and where change proceeds apace, these studies will not be the last word. The issues they address and the questions they pose are likely to remain on the agenda of scholars, politicians and activists for the foreseeable future. 


\section{Bibliography}

Abrar, S. (2000) 'Feminist Intervention and Local Domestic Violence', in G. Stoker (ed), The New Management of British Local Governance. (Basingstoke: Macmillan), 249-267

Barnes, M.. et al. (1999) 'The New Management of Community Care: User Groups, Citizenship and Co-Production', in G. Stoker (ed), The New Management of British Local Governance. (Basingstoke: Macmillan), 112-127

Beynon, J. and Edwards, A.. (1999) 'Community Governance of Crime Control', in G. Stoker (ed), The New Management of British Local Governance. (Basingstoke: Macmillan), 145-167

Clapham, D. et al. (2000) 'User Participation in Community Housing: 'Is Small Really Beautiful'?', in G. Stoker (ed), The New Politics of British Local Governance. (Basingstoke: Macmillan), 215-233

DETR, (1998) Modern Local Government: In Touch with the People. (Department of the Environment, Transport and the Regions)

Doogan, K.. (1999) ‘The Contracting Out of Local Government Services: Its Impact on Jobs, conditions of Service and Labour Markets', in G. Stoker (ed), The New Management of British Local Governance. (Basingstoke: Macmillan), 62-78

Harding, A. (2000) 'Regime Formation in Manchester and Edinburgh', in G. Stoker (ed), The New Politics of British Local Governance. (Basingstoke: Macmillan),

Jessop, B. (2000) 'Governance Failure', in G. Stoker (ed), The New Politics of British Local Governance. (Basingstoke: Macmillan), 11-32

John, P. and Cole, A. (2000) 'Policy Networks and Local Political Leadership in Britain and France', in G. Stoker (ed), The New Management of British Local Governance. (Basingstoke: Macmillan), 72-90 
Marsh, D. and Rhodes, R.A.W. (eds), (1992) Implementing Thatcherite Policies: Audit of An Era. (Buckingham: Open University Press)

Morgan, K. et al. (1999) 'Networking for Local Economic Development', in G. Stoker (ed), The New Management of British Local Governance. (Basingstoke: Macmillan), 181-196

Murdoch, J. et al. (2000) 'Technical Expertise and Public Participation in Planning for Housing: Playing the Numbers Game', in G. Stoker (ed), The New Politics of British Local Governance. (Basingstoke: Macmillan), 198-214

Painter, J. and Goodwin M. (2000) 'Local Government After Fordism: A Regulationist Perspective’ in G. Stoker (ed), The New Politics of British Local Governance. (Basingstoke: Macmillan), 33-53

Pollit, C. et al. (1999) 'Letting Managers Manage: Decentralisation and Opting Out', in G. Stoker (ed), The New Management of British Local Governance. (Basingstoke: Macmillan), 40-61

Ranson, S. et al. (1999) 'The New Management and Governance of Education', in G. Stoker (ed), The New Management of British Local Governance. (Basingstoke: Macmillan), 97-111

Rhodes, R. A.W. (1996) ‘The New Governance: Governing without Government', in Political Studies. XLIV 652-667

Rhodes, R.A.W. (1999) 'Foreword: Governance and Networks', in G. Stoker (ed), The New Management of British Local Governance. (Basingstoke: Macmillan), xii-xxvi

Rhodes, R. A.W. (2000) 'Foreword', in G. Stoker (ed), The New Politics of British Local Governance. (Basingstoke: Macmillan), xi-xv 
Riley, K.. (1999) 'Networks in Post-16 Education and Training', in G. Stoker (ed), The New Management of British Local Governance. (Basingstoke: Macmillan), 168-180

Stoker, G. (1998) ‘Governance as Theory: Five Propositions’, International Social Science Journal, 155

Stoker, G. (1999) 'Introduction: The Unintended Costs and Benefits of New Management Reform for British Local Government', in G. Stoker (ed), The New Management of British Local Governance. (Basingstoke: Macmillan), 1-21

Stewart, J. (2000) The Nature of British Local Government. (Basingstoke: Macmillan)

Stoker G (ed) (1999) The New Management of British Local Governance. (Basingstoke: Macmillan)

Stoker G (ed) (2000) The New Politics of British Local Governance. (Basingstoke: Macmillan)

Young, S.C. (2000) 'Participation Strategies and Local Environmental Politics', in G. Stoker (ed), The New Politics of British Local Governance. (Basingstoke: Macmillan), 181-197

Dr J S Davies

Department of Politics

University of York

Heslington

York YO10 5DD 


\section{The Hollowing Out of Local Demcracy and the 'Fatal Conceit' of Governing without Government}

Review Article Submitted to The British Journal of Politics and International Relations

May 2000

Dr Jonathan S Davies

Department of Politics

University of York

Heslington

York YO10 5DD

Tel: 44(0)1904 433543

Fax: 44(0)1904 433563

E-mail: jsd104@york.ac.uk 